○寺田智祐、高橋一栄、中村暢彦、齋藤秀之、乾 賢一 京大・医・病院薬剤部

\title{
MOLECULAR AND CELL BIOLOGICAL ANALYSES OF DRUG RECOGNITION BY RAT PEPTIDE TRANSPORTERS
}

\author{
Tomohiro TERADA, Kazushige TAKAHASHI, Nobuhiko NAKAMURA, \\ Hideyuki SAITO, and Ken-ichi INUI \\ Department of Pharmacy, Kyoto University Hospital
}

【目的】小腸や腎尿細管上皮細胞に発現する H駆動型ペプチドトランスポータは、経口用 ß-ラクタム抗生物質などのペプチド類似薬物 の輸送担体として機能しており、薬物動態学 的に重要な役割を担っている(1-3)。我々は2種の

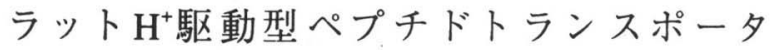

(PEPT1 及ひPEPT2）のCDNAクローニングと、 それに基づく構造・機能並びに臓器分布に関 する比較解析を行ってきた ンスポータの機能的相違点や、 $\beta$-ラク夕ム抗 生物質の腎動態制御における役割など、不明 の点が残されている。そこで本研究では、遺 伝子導入に基づくPEPT1及びPEPT2安定発現上 皮細胞を確立し、薬物認識特性の比較精査を 行うとともに、ラット腎尿細管刷子縁膜にお ける $\beta$-ラク夕ム抗生物質輸送との相関につい て検討を加えた。

\section{【方法】ラットPEPT安定発現系による輸送機} 能発現:リン酸カルシウム共沈法によって、ラッ トPEPT1またPEPT2 cDNA㨂入発現べクター を培盖腎上皮細胞LLC-PK, にトランスフェク ションした。遺伝子導入細胞はG418耐性獲得 をマーカーとして選別し、最終的に $\left[{ }^{14} \mathrm{C}\right]$ Glycylsarcosine (Gly-Sar)輸送活性を指標 として安定発現細胞（LLC-rPEPT1及びLLCrPEPT2細胞）を単離した ${ }^{7-k 8}$ 。単層培養した PEPT発現細胞を用いて、Gly-Sar取り达み活性、 及び種々薬物共存による競合阻害について検
討した。ラット腎皮質刷子縁膜小胞による輸 送機能解析: $\mathrm{Mg}^{2+}$ 沈殿法によって調製したラッ 卜腎皮質刷子縁膜小胞（BBMV）を用い、GlySarの輸送特性について調べた。

【結果・考察】ウエスタンブロッティングの 結果、ラット腎皮質刷子縁膜にはPEPT1

（75kDa）並びにPEPT2（105kDa）の発現が 認められた。腎BBMVによるGly-Sar取り込み の濃度依存性を測定し、輸送パラメー夕を求 めた結果、高親和性型並びに低親和性型の2 種 のペプチドトランスポータの介在することが 示唆された。そこで、LLC-rPEPT1及びLLCrPEPT2細胞におけるGly-Sarの輸送パラメー夕 を算出した結果、PEPT2はPEPT1に比べて高 親和性であることがわかった（Fig. 1）。 BBMVを用いて得られた $2 つ の \mathrm{Km}$ 值と各安定 発現細胞より得られた $\mathrm{Km}$ 值がそれぞれ対応し た值を示したことから、膜小胞系により示さ れた低親和性トランスポータがPEPT1であり、 高親和性トランスポータがPEPT2であること が示唆された8)。
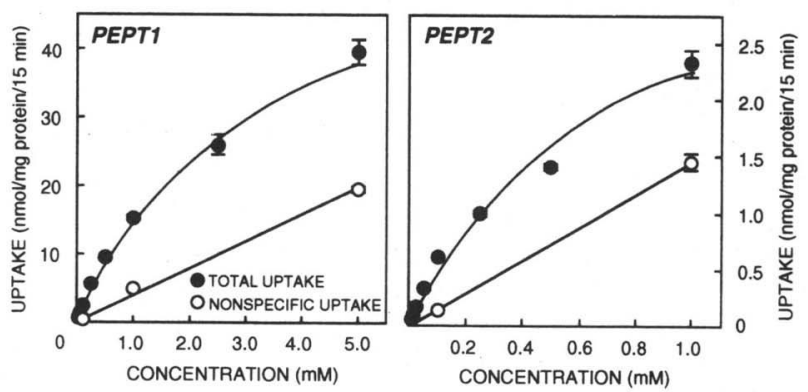

Fig. 1. LLC-rPEPT1並びにLLC-rPEPT2細胞におけるGly-Sar 取り込みの濃度依存性。 
次にGly-Sar取り込み（20 $\mu \mathrm{M} ）$ に及ぼす種々 $\beta$-ラク夕ム抗生物質共存の影響について検討 を行った。LLC-rPEPT1細胞における阻害の強 さは、 cyclacillin > ceftibuten > cefadroxilの順 であり、一方 LLC-rPEPT2 細胞では、 cefadroxil > cyclacillin > ceftibutenの順であっ た（Fig. 2）。種々 $\beta$-ラクタム抗生物質の阻害

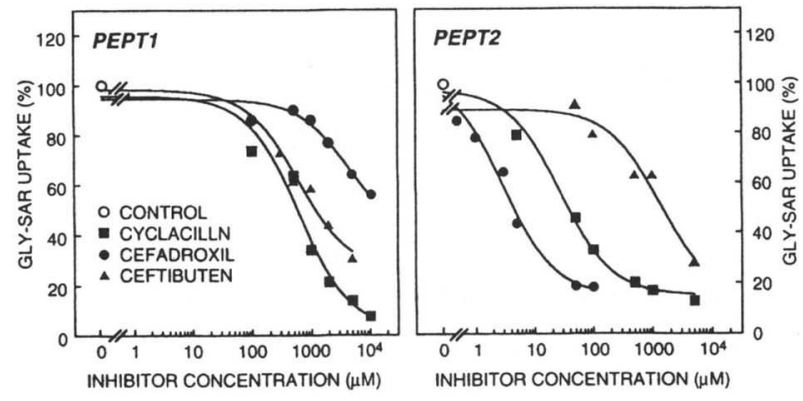

Fig. 2. LLC-rPEPT1並びにLLC-rPEPT2細胞によるGly-Sar 取り込みに及ほす $\beta$-ラクタム抗生物質の阻害曲線.

定数（Ki值）を阻害曲線より算出 LPEPT 1 と PEPT2間で比較した結果、 $\alpha$-アミノ基を有す る $\beta$-ラク夕ム抗生物質に対しては、PEPT2の 方がより高い親和性を示し、一方 $\alpha$-アミノ基 を持たないceftibutenや cefiximeに対しては PEPT1の方が高い親和性を有することが判明 した8)。また一部の薬物を除いてラットPEPT1 から求められた Ki值は、ヒト腸由来の培養上
皮細胞Caco-2（ヒトPEPT1発現細胞）より算 出された Ki 值とほほ対応していた。一方腎 BBMVにおけるGly-Sar取り込みはcefadroxil> cyclacillin > ceftibuten の順に阻害され、 LLC-rPEPT2細胞と同様のパターンを示した。 PEPT安定発現細胞並びにBBMVにおいて得ら れた種々 $\beta$-ラク夕ム抗生物質の $\mathrm{Ki}$ 值を比較解 析したところ、BBMVにおけるKi值はPEPT1 よりもPEPT2のKi值と良い相関を示した。従っ てこれらのß-ラクタム抗生物質は低濃度域に おいては尿細管刷子縁膜に発現するPEPT2 と 強く相互作用することが示された。さらに化 学修飾並びに点変異導入法によって、第2及び 4膜貫通ドメインに位置する保存性ヒスチジン 残基がPEPT1の多様な薬物認識機構に関わっ ている可能性が示された9”。

今後PEPT1並びにPEPT2の輸送活性調節機 構、基質認識領域の検索及び種差に関する分 子的解析を展開することによって、ペプチド 類似薬物の体内動態制御機構、並びにペプチ ドトランスポータをターゲットとする医薬品 分子設計や製剂開発に新たな情報を提供し得 るものと考えられる。

ABSTRACT PEPT1 and PEPT2 are $\mathrm{H}^{+}$-coupled peptide transporters expressed preferentially in the intestine and kidney, respectively, which mediate uphill transport of oligopeptides and peptide-like drugs such as $\beta$-lactam antibiotics. In the present study, we have compared the recognition of $\beta$-lactam antibiotics by LLC-PK 1 cells stably transfected with rat PEPT1 or PEPT2 cDNA. Among the examined drugs, cyclacillin (aminopenicillin) and cefadroxil (aminocephalosporin) showed the most potent inhibitory effects on glycylsarcosine uptake in PEPT1- and PEPT2-expressing cells, respectively. Comparison of the $\mathrm{Ki}$ values of $\beta$-lactam antibiotics between PEPT1- and PEPT2-expressing cells suggested that PEPT2 had a much higher affinity for $\beta$-lactam antibiotics with an $\alpha$-amino group. We have examined interactions of $\beta$-lactam antibiotics with rat renal brush-border membrane vesicles, in which PEPT1 and PEPT2 appeared to be coexpressed. The apparent Ki values of the antibiotics for glycylsarcosine transport were closely correlated with those in the PEPT2-expressing cells, suggesting that $\beta$-lactam antibiotics interact predominantly with PEPT2 rather than PEPT1 in renal brush-border membranes. In conclusion, 1) PEPT1 and PEPT2 show different recognitions of $\beta$-lactam antibiotics, and 2) $\beta$-lactam antibiotics predominantly interact with renal PEPT2 at pharmacological concentrations.

REFERENCES (1) T. Okano et al., J. Biol. Chem., 261, 14130 (1986) (2) K. Inui et al., J. Pharmacol. Exp. Ther., 261, 195 (1992) (3) S. Matsumoto et al., J. Pharmacol. Exp. Ther., 270, 498 (1994) (4) H. Saito et al., J. Pharmacol. Exp. Ther., 275, 1631 (1995) (5) H. Saito et al., Biochim. Biophys. Acta, 1280, 173 (1996) (6) H. Ogihara et al., Biochem. Biophys. Res. Commun., 220, 848 (1996) (7) T. Terada et al., J. Pharmacol. Exp. Ther., 281, 1415 (1997) (8) T. Terada et al., Am. J. Physiol., in press. (9) T. Terada et al., FEBS Lett., 394, 196 (1996) 